At the end of the book there is a chapter devoted to the ocular manifestations of general diseases, and another to ocular therapeutics, in which prescriptions of lotions, ointments, and other medicaments, are given in full.

The final chapter states the visual requirements for British and Indian Public Services.

There are many points of practical interest in this book which will meet the requirements of the general practitioner and the student.

\title{
CORRESPONDENCE
}

\section{PROPTOSIS, PROTHESIS AND PROSTHESIS}

To the Editors of The British Journal of Ophthalmology.

SIRS,-It is very noticeable that a number of people, some teachers included, pronounce the word proptosis as if the two syllables were "prop" and "tosis." The word is, of course, "pro " and "ptosis," a falling forwards.

Then "prothesis" is a curious word. We use it commonly enough, but it is not advisable to employ it to a layman when we mean an artificial eye or a wooden leg, since its main dictionary meaning is "a place in a church on which the elements for the eucharist are put previous to their being placed on the altar." According to the Imperial Dictionary, "prothesis" has as its primary meaning the ecclesiastical one, and as its secondary meaning the surgical one, whereas "prosthesis" primarily has the surgical meaning and secondarily a philological one, i.e., the adding of one or more letters to the commencement of a word such as bereft. It would therefore appear to be correct to refer to an artificial eye as a prosthesis rather than a prothesis.

$$
\begin{aligned}
& \text { Yours faithfully, } \\
& \text { ERNEST THOMSON. }
\end{aligned}
$$

\section{BLINDNESS IN INDIA}

To the Editors of The British Journal of Ophthalmology.

SIRS,-With reference to Col. Wright's communication on "Blindness in India" which appears in your April issue, may I request you to publish the following little expianation. 
The Blind Relief Association was started by Mr. C. G. Henderson, I.C.S. in 1913, who, two years ago, gave up his appointment so as to be able to devote the whole of his time to this work. Last year, feeling the need for a more extensive effort the All India Blind Relief Association came into being to co-ordinate and extend the already existing Blind Relief Association.

This Association has never stated that it is the only agency for the prevention of blindness in India, and far from belittling the Government's effort, wishes whenever possible to work in conjunction with Government institutions. Its work is in rural areas, where no other agency exists for this one particular purpose, and where it is most needed. At present its activities are in the Bombay Presidency, which has a population of 26 millions and Government institutions dealing specifically with this problem number five only. Considering the fact that 80 per cent. of the population of India live in villages, which number more than half a million, the efforts of the Government can be said to have merely touched the fringe of the problem because its good work is mainly confined to towns and cities of the subcontinent which number 89 and constitute about 20 per cent. of the population. Urgent and absolute necessity has brought into existence the All India Blind Relief Association.

\section{Yours truly, \\ B. P. Banaji, F.R.C.S.I.}

Hon. Ophthalmic Surgeon to the Association.

We have also received a letter on this subject, to a similar effect, from the Organising Secretary of the Blind Relief Association.EDITORS.

\section{NOTES}

Honour

ThE Leslie Dana Gold Medal, which is awarded annually in recognition of outstanding work on behalf of prevention of blindness, was presented on May 24, 1930, to Dr. G. E. de Schweinitz, of Philadelphia.

****** * *

$\begin{array}{cl}\begin{array}{c}\text { Oxford } \\ \text { Ophthalmological } \\ \text { Congress }\end{array} & \text { The 20th Meeting will be held in Oxford on } \\ 11 \text { and 12. Friday and Saturday, July 10, } & \end{array}$

There will be a discussion on Toxic Amblyopia and Retrobulbar Neuritis, introduced by Dr. Traquair, Sir Farquhar Buzzard, 13t., K.C.V.O., and Professor J. A. Gunn, on Thursday morning. 